\title{
MOSSES (BRYOPHYTA) OF THE KOSTOMUKSHA STATE NATURE RESERVE, RUSSIA
}

\author{
Margarita A. Boychuk \\ Institute of Biology of Karelian Research Centre of RAS, Russia \\ e-mail:boychuk@krc.karelia.ru
}

Received: 15.05.2020. Revised: 28.01.2021. Accepted: 10.02.2021.

\begin{abstract}
The Kostomuksha State Nature Reserve (KSNR) is located in northwestern Russia, in the Republic of Karelia (hereinafter - Karelia), near the Finnish border. It has an area of $492.76 \mathrm{~km}^{2}$. This Protected Area was established in 1983 to protect a typical area in the north-taiga subzone of European Russia. The paper contains the results of a long-term inventory of mosses. We critically checked own samples from 1995-1998 and 2016, deposited into the Herbarium of the Karelian Research Centre of RAS (PTZ). Own samples, collected in 2010, 2012 and 2017-2019, have been processed. All available data, including literature, were summarised. An annotated list of 180 moss species was compiled. It makes up 70\% of the moss flora of the Kuitozero-Leksozero floristic province and about $35 \%$ of Karelia's moss flora. Twenty-six species are reported for the KSNR for the first time. Of them, six species (Campyliadelphus elodes, Racomitrium fasciculare, Didymodon rigidulus, Eurhynchium angustirete, Grimmia elatior, Grimmia torquata) are new to the Kuitozero-Leksozero floristic province. The distribution of some known species was clarified based on the latest records. The taxonomic and ecological-coenotic structure of the moss flora has been revealed. Most moss species $(75 \%)$ are widespread in the north-taiga subzone of Karelia. There are five species included in the Red Data Book of the Republic of Karelia (2020): Campyliadelphus elodes (3 VU), Eurhynchium angustirete (3 VU), Neckera pennata (3 NT), Diobelonella palustris $[=D i-$ chodontium palustre] (3 VU), Sphagnum auriculatum (3 VU). For the first three protected species KSNR is the northernmost locality in Karelia and for Diobelonella palustris it is the only locality in Karelia. Nine species (Callicladium haldanianum (NT), Campyliadelphus elodes (NT), Dicranum spadiceum (VU), Mnium lycopodioides (NT), Neckera pennata (VU), Schistostega pennata (VU), Sphagnum contortum (NT), Sphagnum inundatum (EN), and Sphagnum subnitens (NT)) are included in the Red List of Finnish species (2019). Seven species (Campyliadelphus elodes (NT), Fontinalis dalecarlica (NT), Helodium blandowii (NT), Meesia triquetra (NT), Scorpidium scorpioides (NT), Splachnum ampullaceum (NT), and Tomentypnum nitens (NT)) are listed on the European Red List (2019). The moss flora of KSNR was compared with a few other Protected Areas in European Russia, along the country borders, in the north-taiga, namely Pasvik State Nature Reserve (Murmansk Region), Paanajärvi National Park, Kalevalsky National Park, and projected Tulos Nature Sanctuary (all three - Karelia).
\end{abstract}

Key words: flora, Protected Area, Red Data Book, sample, species

\section{Introduction}

Biodiversity studies in border areas are of high scientific interest, because a strict border regime contributes to the preservation of undisturbed ecosystems. In the north-taiga subzone of European Russia near the Norwegian-Russian border (Murmansk Region), studies of the moss flora were conducted in Pasvik State Nature Reserve (Boychuk \& Borovichev, 2018; Borovichev \& Boychuk, 2019), Paanajärvi National Park near the Finnish-Russian border (Republic of Karelia, hereinafter - Karelia) (Brotherus, 1923; Roivainen, 1929; Pesola, 1934; Hällström, 1937; Kalliola, 1939; Tuomikoski, 1939; Auer, 1942; Maksimov, 1995; Halonen \& Ulvinen, 1996; Maksimov \& Boychuk, 2011), Kalevalsky National Park (Boychuk, 1998) and projected Tulos Nature Sanctuary (Maksimov et al., 2009). Lists of mosses provide a basis to estimate the biodiversity.

In 1987-1991, a research team of the Geography Department of Moscow State University conducted studies under the Project «Compiling a series of large-scale biogeographic maps of Kostomuksha State Nature Reserve (hereinafter - KSNR)». The Moscow State University Report of 1992 contains a list of the 40 widespread moss species, but the sampling sites were not specified. While studying the aquatic flora and vegetation of Lake Kamennoe in 1993, Mäkirinta et al. (1997) found nine moss species. In 1995-1998, Boychuk (2001) carried out the investigations of moss flora in the KSNR and compiled the first list of 150 species. In 2016, nine small islands on Lake Kamennoe were studied. There were 87 moss species found (Boychuk \& Galanina, 2018), including 11 new to the study area.

The aim of the present study was to clarify, supplement, summarise, and analyse data on the mosses in the KSNR and compare them with other Protected Areas in European Russia, along the country borders, in the north-taiga. 


\section{Material and Methods}

The KSNR (64.473056 ${ }^{\circ} \mathrm{N}, 30.274167^{\circ} \mathrm{E}$, 150-300 m a.s.l.) is located in northwestern Russia, in Karelia, near the Finnish border (Fig. 1). It covers an area of $492.76 \mathrm{~km}^{2}$. The KSNR was established in 1983 to protect a typical area in the north-taiga subzone of European Russia (Belousova et al., 1988). In 1990, this Protected Area became a part of the Finnish-Russian Nature Reserve Friendship, the first International Nature Reserve near the Russian border.

Geologically, the KSNR is located on the Fennoscandian (Baltic) shield consisting predominantly of the oldest (Lower Archaean) rocks, such as diorite, gneiss, tonalite, plagiogranite and migmatite (Gorkovets \& Rayevskaya, 1997). The crystalline basement is almost entirely overlain by Quaternary rocks, but is exposed in some places. Tectonic faults occur. The KSNR is situated on the eastern slope of the West Karelian Highland. It is dominated by denudation-tectonic ridge-hilly to hilly relief.

In the KSNR, a hydrographic network is formed by 250 lakes as well as by rivers and brooks. The largest water body is Lake Kamennoe, covering about $20 \%$ of the Protected Area. There are 98 islands, mostly of small size. The water flows from the Lake Kamennoe through the River Kamennaya towards the White Sea. The River Kamennaya has many rapids. The biggest one is called Tzar Porog, where the water falls from an 8-m height.

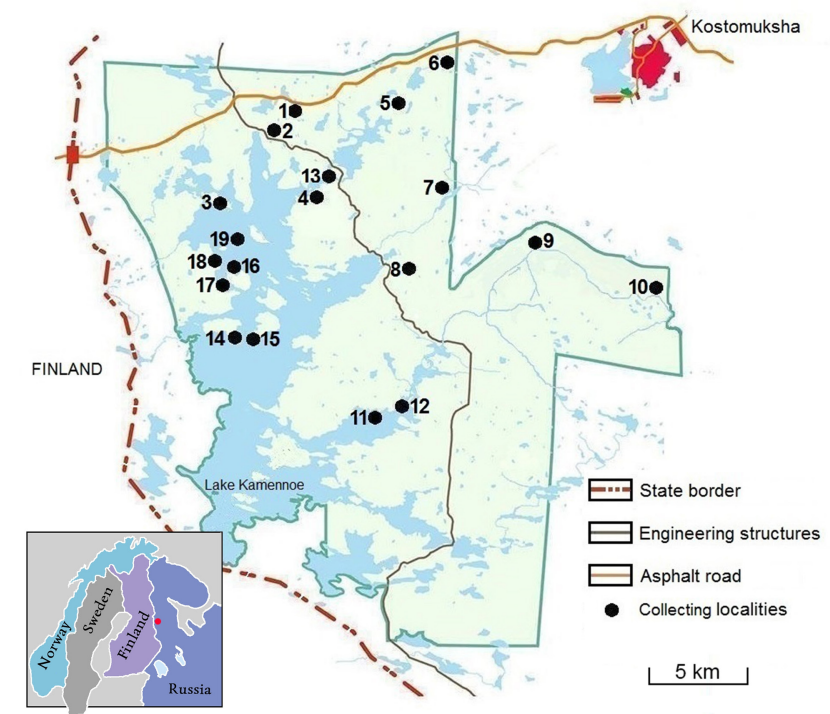

Fig. 1. The map of the Kostomuksha State Nature Reserve (Russia) indicating the sampling sites. Designations: 1 - phenological route, 2 - Ehrimanvaara, 3 - Akonlahti, 4 - Integrated Monitoring Station, 5 - Packmen's Path eco-route, 6 - Sarikkojärvi, 7 - Munozero, 8 - canyon Kamennye Vorota, 9 - Tzar Porog on the River Kamennaya, 10 - Nizhnyaya Izba, 11-19 - islands on Lake Kamennoe.
The study area has a temperate-continental climate. Winters are mild and long, while summers are short and cool. The mean annual air temperature is $+1.1^{\circ} \mathrm{C}$. Maximum air temperatures are up to $-49^{\circ} \mathrm{C}$ in winter and $+33^{\circ} \mathrm{C}$ in summer. The mean annual precipitation is $540 \mathrm{~mm}$ (Salo, 1997). The soil cover is heterogenous and displays a mosaic pattern. The zonal Al-Fehumus soils (Podzols) are the most widespread in the Protected Area (Bakhmet et al., 2021). Poorly developed Leptosols occur on outcrops. As moisture content increases, Histosols are formed in depressions between the ridges and hills.

According to Aleksandrova \& Jurkovskaya (1989), the KSNR lies in the north-taiga subzone. It is a part of the West Karelian geobotanical district in the Kola-Karelian subprovince of the North European province of the Eurasian taiga zone. Forests cover over $60 \%$ of the KSNR. Of them, pine (Pinus sylvestris L.) forests make up $85 \%$ of the forested area, spruce (Picea abies (L.) H. Karst.) forests cover about $15 \%$. In the forested area, 80-160-year-old forest stands prevail, while the maximum ages of pine and spruce trees are 450 and 300 years, respectively. Derivative birch (Betula pubescens Ehrh. or B. pendula Roth) and aspen (Populus tremula L.) forests occur occasionally (Gromtsev, 2009). Mires occupy 20\% of the KSNR. Raised bogs, poor fens and aapa are predominant mire complexes in the KSNR (Kolomytsev \& Kuznetsov, 1997). Meadows cover a small area. In addition, there are other anthropogenic habitats and substrates. In accordance with Ramenskaya (1960), the KSNR is a part of the Kuitozero-Leksozero floristic province.

The article is based on the personal collections of the author. The moss samples collected in 1995-1998 and 2016 and stored in the Herbarium of the Karelian Research Centre of RAS (PTZ) were critically revised and checked. In 2010, 2012 and 2017-2019, the author conducted a moss flora inventory in the KSNR (Fig. 1: localities 1, 3-5, 7-10). About 900 moss samples from various habitats and substrates were collected. The article takes into account the available literature data, including Mäkirinta et al. (1997), Boychuk (2001) (Fig. 1: localities 1, 2, 4, 6, 7, 9, and 10), Boychuk \& Galanina (2018) (Fig. 1: locations 11-19). The data, representing an annotated list of mosses in the KSNR, were compiled in the Electronic Supplement 1 . The Latin names of species are given according to Hodgetts et al. (2020). To compare, lists of taxa (species, genera, families) in the KSNR and four other Protected Areas in North European Russia, along the country borders, in the north-taiga, namely Pasvik State Nature Reserve, Paanajärvi National Park, Kalevalsky National Park, projected Tulos Na- 
ture Sanctuary, are given in Electronic Supplement 2. We performed a cluster analysis of the species lists using UPGMA (unweighted pair group method with arithmetic mean) method and Jaccard similarity index (Tamarin \& Schmidt, 1975). The analysis was performed in PAST v. 3.25 (Hammer et al., 2001).

\section{Results and Discussion}

Critical revision of the moss samples stored in PTZ Herbarium has demonstrated that eleven species should be excluded from the list of mosses in the KSNR (Boychuk, 2001). Ptychostomum imbricatulum (Müll.Hal.) Holyoak \& N.Pedersen could not be confirmed because we found no sporogonia in the sample. Racomitrium affine (F.Weber \& D.Mohr) Lindb. was re-identified as Racomitrium microcarpon (Hedw.) Brid. Fontinalis squamosa Hedw. was re-identified as F. dalecarlica Schimp. Plasteurhynchium striatulum (Spruce) M.Fleisch. was re-identified as Sciuro-hypnum plumosum (Hedw.) Ignatov \& Huttunen. We found no samples confirming Oncophorus virens (Hedw.) Brid. Schistidium rivulare (Brid.) Podp. was re-identified as Schistidium apocarpum (Hedw.) Bruch \& Schimp. We found no herbarium specimens confirming Scorpidium cossonii (Schimp.) Hedenäs. We found no samples confirming Sphagnum cuspidatum Ehrh. ex Hoffm. Jochenia pallescens (Hedw.) Hedenäs, Schlesak \& D.Quandt was re-identified as Hypnum cupressiforme Hedw. We found no herbarium confirming Ptychostomum pallens (Sw. ex anon.) J.R. Spence. Ulota crispula Bruch was re-identified as Ulota curvifolia (Wahlenb.) Lilj. Three species (Hypnum cupressiforme, Sciuro-hypnum plumosum, Schistidium apocarpum) should be added to the list of mosses in the KSNR, because they were not included mistakenly in this checklist previously. Two species (Philonotis caespitosa Jur., Schistidium rivulare) of insular mosses (Boychuk \& Galanina, 2018) were reidentified as Meesia triquetra (L. ex Jolycl.) Ångstr. and Schistidium apocarpum respectively.

Our revision of samples, collected in 2010, 2012, 2017-2019, has resulted in finding new locations of both previously known and newly-registered (26) species in the flora of the KSNR. For the first time, the following mosses have been found: Blindia acuta (Hedw.) Bruch \& Schimp., Brachytheciastrum velutinum (Hedw.) Ignatov \& Huttunen, Brachythecium erythrorrhizon Schimp., Buxbaumia aphylla Hedw., Callicladium haldanianum (Grev.) H.A. Crum, Campyliadelphus elodes (Lindb.) Kanda, Racomitrium fasciculare (Hedw.) Brid., Dicranella crispa (Hedw.) Schimp., Dicranella subu- lata (Hedw.) Schimp., Dicranum spurium Hedw., Didymodon rigidulus Hedw., Ditrichum heteromallum (Hedw.) E. Britton, Eurhynchiastrum pulchellum (Hedw.) Ignatov \& Huttunen, Eurhynchium angustirete (Broth.) T.J. Kop., Funaria hygrometrica Hedw., Grimmia elatior Bruch ex Bals.-Criv. \& De Not., Grimmia torquata Drumm., Heterocladiella dimorpha (Brid.) Ignatov \& Fedosov, Hygroamblystegium fluviatile (Hedw.) Loeske, Mnium lycopodioides Schwägr., Neckera pennata Hedw., Pogonatum dentatum (Menzies ex Brid.) Brid., Pylaisia polyantha (Hedw.) Schimp., Sphagnum auriculatum Schimp., Sphagnum quinquefarium (Braithw.) Warnst., and Sphagnum rubellum Wilson.

The obtained data show that there are now 180 moss species known within the KSNR. (Electronic Supplement 1, Electronic Supplement 2). It makes up $70 \%$ of the moss flora of the Kuitozero-Leksozero floristic province and $35 \%$ of Karelia's moss flora (Volkova \& Maksimov, 1993; Maksimov et al., 2003; Boychuk \& Lantratova, 2009; Maksimov et al., 2009; Afonina et al., 2010; Sofronova et al., 2012, 2017). Six species (Campyliadelphus elodes, Racomitrium fasciculare, Didymodon rigidulus, Eurhynchium angustirete, Grimmia elatior, and Grimmia torquata) are reported for the first time for the Kuitozero-Leksozero floristic province.

The 180 moss species belong to 87 genera and 44 families. In the KSNR, the richest family was Sphagnaceae (33 species), followed by Dicranaceae (14), Mniaceae (14), Brachytheciaceae (12), Calliergonaceae (11), Polytrichaceae (10), Amblystegiaceae (11), Grimmiaceae (8), Splachnaceae (5), Hylocomiaceae (5). Sphagnum is the leading genus in terms of species number (33 species out of 39 known in Karelia). The genera Dicranum, Polytrichum, Brachythecium include 13 species, 6 species, 5 species, accordingly. In terms of taxonomic composition, the studied flora reflects the boreal regional position of KSNR.

Analysis of the habitat preferences of mosses in the KSNR (Fig. 2) showed that the highest number of species (100) prefer semi-aquatic habitats. This can be explained by the noticeable presence of the clean (i.e. not affected by human activities) Lake Kamennoe with various shore types (i.e. sandy, boulder, paludified), favourable microclimatic and hydrological conditions, less competition with vascular plants. Along the Lake Kamennoe shores, we often registered Calliergonella lindbergii (Mitt.) Hedenäs, Climacium dendroides (Hedw.) F. Weber \& D. Mohr, Dichelyma falcatum (Hedw.) Myrin, Leptodictyum riparium (Hedw.) Warnst., Sphagnum subfulvum Sjors. Tzar Porog on the River Kamennaya (Fig. 
1: location 9) deserves special attention. Such species as Blindia acuta, Hygroamblystegium fluviatile, Platyhypnum smithii (Sw.) Ochyra, and Campyliadelphus elodes inhabit only this location.

In forest habitats, the moss richness ( 70 species) is determined by the typological spectrum (Gromtsev, 2009), microhabitat conditions (mostly soil moisture and shading), substrate (bared soil, forest floor, rotten wood, boulders and rocky outcrops, base and trunk of trees, animal droppings). The most common species in pine forests, spruce forests, and birch forests are Pleurozium schreberi (Willd. ex Brid.) Mitt., Hylocomium splendens (Hedw.) Schimp., Dicranum scoparium Hedw., Dicranum polysetum Sw. ex anon., and Polytrichum commune Hedw. Scarce aspen trees, occurring in mixed forests and near the former villages, are of special interest. On the aspen trunks, Amblystegium serpens (Hedw.) Schimp., Eurhynchiastrum pulchellum, Eurhynchium angustirete, Neckera pennata, Pylaisia polyantha, and Campylophyllopsis sommerfeltii (Myrin) Ochyra were found.

The scarce character of the moss occurrence on mires ( 65 species) seems to be caused by the presence of bogs and poor fens (Kolomytsev \& Kuznetsov, 1997). As there are no rich fens, some of the typical species (e.g. Cinclidium stygium Sw., Hamatocaulis vernicosus (Mitt.) Hedenäs, Drepanocladus trifarius (F.Weber \& D.Mohr) Broth. ex Paris, Scorpidium cossonii) were not found. Other mosses (e.g. Ptychostomum pseudotriquetrum (Hedw.) J.R.Spence \& H.P.Ramsay ex Holyoak \& N.Pedersen, Calliergon giganteum (Schimp.) Kindb., Meesia triquetra, Scorpidium scorpioides (Hedw.) Limpr., Sphagnum contortum Schultz) were found only on the river banks or lake shores.

The bedrock moss flora was characterised by a low diversity ( 31 species) because of the prevalence of felsic rocks (Gorkovets \& Rayevskaya, 1997). Andreaea rupestris Hedw., Racomitrium microcarpon, Cynodontium strumiferum (Hedw.) Lindb., Hymenoloma crispulum (Hedw.) Ochyra, Paraleucobryum longifolium (Hedw.) Loeske, and Schistidium apocarpum were common on this habitat type. Being more sensitive to the chemical composition of rocks, Amphidium lapponicum (Hedw.) Schimp., Grimmia torquata, Heterocladiella dimorpha, and Ulota curvifolia were found in the canyon Kamennye Vorota and near the Tzar Porog. These species may indicate the local presence of calcium-bearing rocks at the above-mentioned locations.

There were 25 species reported from meadows on abandoned farmlands and in abandoned villages
(Fig. 1: locations 2, 3). Most of them (e.g. Dicranum scoparium, Pohlia nutans (Hedw.) Lindb., and Polytrichum juniperinum Hedw.) occur in other habitats, too. Fifteen species were found in other disturbed areas such as roadsides, old quarries, and former border post areas. Didymodon rigidulus is of special interest. Previously, Volkova \& Maksimov (1993) noted this species only from three Karelian floristic provinces (Northwestern Montane, Trans-Onega, and Priladozhsky), where calcium-bearing rocks are abundant. In KSNR, this species was found on a concrete slab from an old frontier building, similar to carbonate substrate.

In relation to the substrate (Fig. 3), the highest number of mosses was terricolous (116 species on soil), followed by rupicolous (on boulders and bedrock exposures, 65 species), corticicolous (on tree bark, 28 species), and epixilous (on rotting wood, 23 species). Some species prefer other substrates, including concrete slab (three species), brick (two species), brown bear (Ursus arctos Linnaeus, 1758) feces (three species), reindeer (Rangifer tarandus Linnaeus, 1758) bones (two species). There were 146 monosubstrate (preferring only one substrate) species and 34 polysubstrate species (preferring more than one substrate).

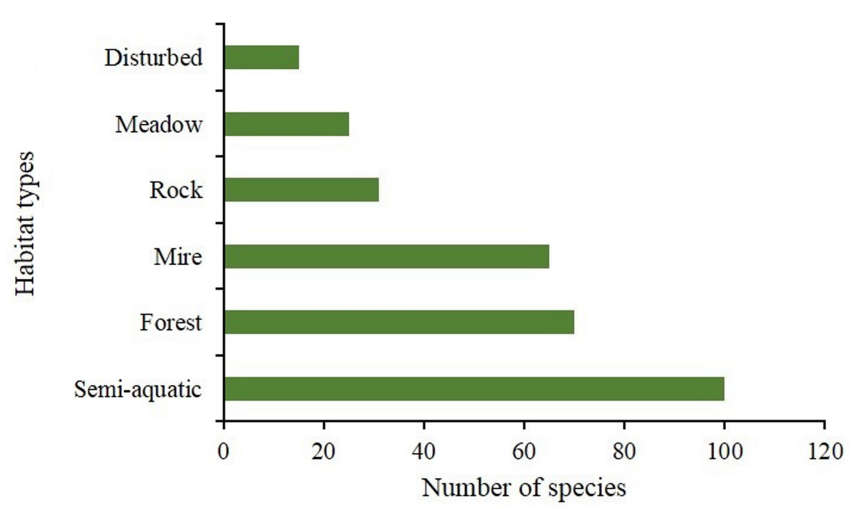

Fig. 2. Habitat preferences of the moss species in the Kostomuksha State Nature Reserve (Russia).

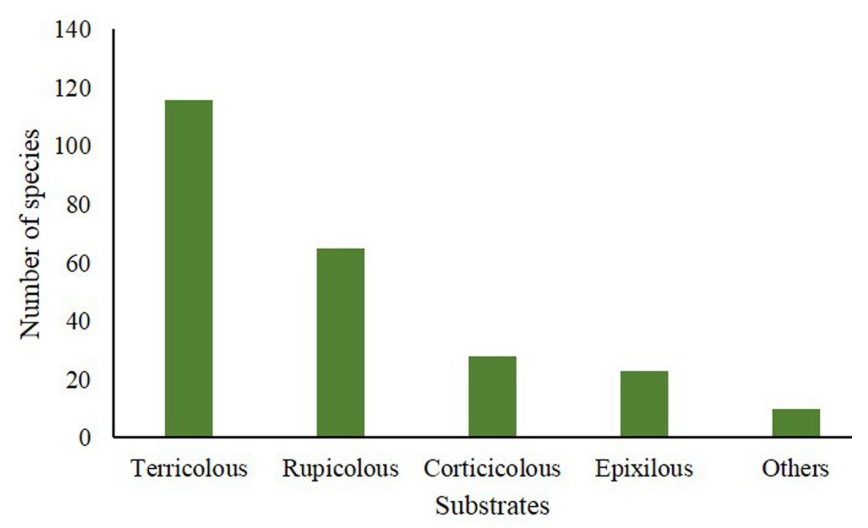

Fig. 3. Substrate preferences of the moss species in the Kostomuksha State Nature Reserve (Russia). 
Most species (75\%) are widespread, occurring in four or all five floristic provinces in the north taiga zone of Karelia (Volkova \& Maksimov, 1993; Maksimov et al., 2003). Five rare species are listed in the Red Data Book of the Republic of Karelia (2020). They are characterised below.

Campyliadelphus elodes (Red Data Book category: 3 VU) was found on wet boulders of Tzar Porog on the River Kamennaya (Fig. 1: location 9). It is the fourth (Wahlberg, 1998; Afonina et al., 2009; Sofronova et al., 2012) and northernmost location in Karelia.

Diobelonella palustris (Dicks.) Ochyra (= Dichodontium palustre (Dicks.) M.Stech.) (Red Data Book category: $3 \mathrm{VU}$ ) was discovered on wet soil on the River Kamennaya bank (Fig. 1: location 10). It is the only location in Karelia. This northern species seems to be occurring at the southern boundary of its range.

Eurhynchium angustirete (Red Data Book category: 3 VU) was discovered near the Tzar Porog on the River Kamennaya (Fig. 1: location 9), at the base of an aspen tree trunk in grass-moss spruce forest (with birch and aspen). It is the fifth (Koponen, 1967; Afonina et al., 2009; Sofronova et al., 2017; Maksimov \& Maksimova, 2018) and northernmost location of this species in both Karelia and European Russia. In KSNR, this species occurs at the northern boundary of its natural range.

Neckera pennata (Red Data Book category: 3 NT) was collected near the Tzar Porog on the River Kamennaya (Fig. 1: location 9), on aspen tree bark in herbaceous spruce forest (with pine, birch and aspen). It is the northernmost location in Karelia. This species is not rare in the middle taiga subzone of Karelia, while in the north taiga subzone of Karelia, it is known only in the projected Tulos Nature Sanctuary (Maksimov et al., 2009).

Sphagnum auriculatum (Red Data Book category: $3 \mathrm{VU}$ ) was found in the vicinity of the site Nizhnyaya Izba (Fig. 1: location 10), on soil in a Carex-Sphagnum community on the River Kamennaya bank. It is the fifth location in Karelia (Maksimov \& Maksimova, 2008; Maksimov \& Boychuk, 2011).

Nine moss species known in the KSNR are protected in Finland (Hyvärinen et al., 2019). These are Callicladium haldanianum (NT), Campyliadelphus elodes (NT), Dicranum spadiceum J.E. Zetterst. (VU), Mnium lycopodioides (NT), Neckera pennata (VU), Schistostega pennata (Hedw.) F. Weber \& D. Mohr (VU), Sphagnum contortum (NT), S. inundatum Russow (EN), and S. subnitens Russow \& Warnst.
(NT). Seven moss species found in KSNR are listed on the European Red List (Hodgetts et al., 2019), including Campyliadelphus elodes (NT), Fontinalis dalecarlica (NT), Helodium blandowii (F. Weber \& D. Mohr) Warnst. (NT), Meesia triquetra (NT), Scorpidium scorpioides (NT), Splachnum ampullaceum Hedw. (NT), and Tomentypnum nitens (Hedw.) Loeske (NT).

We have compared the moss species composition in the KSNR with four other Protected Areas in European Russia, along the country borders, in the north-taiga (Table). We found that the richest moss flora was in Paanajärvi National Park (338 species) characterised by a larger area, higher landscape diversity and longer (since 1842) period of its investigations by Finnish botanists (e.g. Brotherus, 1923; Roivainen, 1929; Pesola, 1934; Hällström, 1937; Kalliola, 1939; Tuomikoski, 1939; Auer, 1942). A smaller number of mosses (200 species) was found in the Pasvik State Nature Reserve. This Protected Area is associated with a lower presence of calcium-bearing rocks, but its moss flora is well-studied. In terms of species saturation (i.e. ratio of the species' number per Protected Area), the Pasvik State Nature Reserve is characterised by a maximum value (1.36) with a minimum area among the compared Protected Areas. In KSNR, the moss flora is more similar to the flora of the projected Tulos Nature Sanctuary (132 common species). We found that the Kalevalsky National Park has the smallest number of the moss species. During the justification of this Protected Area, 158 species were revealed (Boychuk, 1998), but when it was founded (in 2007), its boundaries were reduced. Consequently, the number of moss species became lower (117, of which 111 are common within the KSNR). The Kalevalsky National Park, projected Tulos Nature Sanctuary and KSNR are closely located, have similar natural conditions and belong to the same Kuitozero-Leksozero floristic province. These three Protected Areas were placed into the same cluster in Fig. 4.

In total, all five areas, the Kostomuksha State Nature Reserve, Pasvik State Nature Reserve, Paanajärvi National Park, Kalevalsky National Park, and projected Tulos Nature Sanctuary, serve to be a home for 380 moss species from 147 genera and 60 families (Electronic Supplement 2). This is about two-third of the moss flora of Karelia and the Murmansk region. This demonstrates the high representativeness of these Protected Areas in European Russia, along the country borders, in the north-taiga for the moss conservation. 
Table. Moss diversity in the Kostomuksha State Nature Reserve (Russia) and other Protected Areas in European Russia, along the country borders, in the north-taiga

\begin{tabular}{|l|c|c|c|c|l|}
\hline \multicolumn{1}{|c|}{ Protected Area } & Co-ordinates & $\begin{array}{c}\text { Area, } \\
\mathrm{km}^{2}\end{array}$ & $\begin{array}{c}\text { Total number } \\
\text { of species }\end{array}$ & $\begin{array}{c}\text { Species } \\
\text { saturation }\end{array}$ & References \\
\hline Pasvik State Nature Reserve & $\begin{array}{l}69.066667^{\circ} \mathrm{N}, \\
29.186111^{\circ} \mathrm{E}\end{array}$ & 147 & 200 & 1.36 & $\begin{array}{l}\text { Boychuk \& Borovichev, 2018; Boro- } \\
\text { vichev \& Boychuk, 2019 }\end{array}$ \\
\hline Paanajärvi National Park & $\begin{array}{l}65.761344^{\circ} \mathrm{N}, \\
31.072919^{\circ} \mathrm{E}\end{array}$ & 1045 & 338 & 0.32 & $\begin{array}{l}\text { Maksimov, 1995; Halonen \& Ulvinen, } \\
1996 ; \text { Maksimov \& Boychuk, 2011 }\end{array}$ \\
\hline Kalevalsky National Park & $\begin{array}{l}64.991667^{\circ} \mathrm{N}, \\
30.212500^{\circ} \mathrm{E}\end{array}$ & 744 & 117 & 0.16 & Boychuk, 1998 \\
\hline Kostomuksha State Nature Reserve & $\begin{array}{l}64.473056^{\circ} \mathrm{N}, \\
30.274167^{\circ} \mathrm{E}\end{array}$ & 493 & 180 & 0.37 & Present paper \\
\hline Projected Tulos Nature Sanctuary & $\begin{array}{l}63.563889^{\circ} \mathrm{N}, \\
30.466667^{\circ} \mathrm{E}\end{array}$ & 685 & 155 & 0.23 & Maksimov et al., 2009 \\
\hline
\end{tabular}

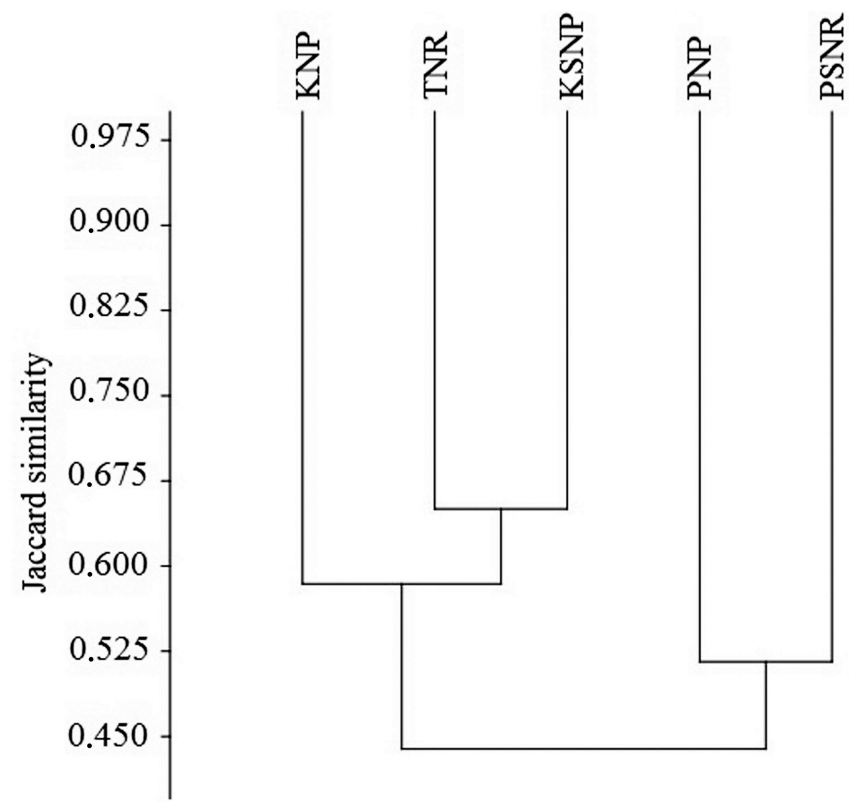

Fig. 4. The similarity of the species composition of the five Protected Areas in European Russia, along the country borders, in the north-taiga, based on the Jaccard similarity index (Tamarin \& Schmidt, 1975). Designations: KSNR - Kostomuksha State Nature Reserve, PSNR Pasvik State Nature Reserve, PNP - Paanajärvi National Park, KNP - Kalevalsky National Park, TNS - projected Tulos Nature Sanctuary.

\section{Conclusions}

In the KSNR, 180 moss species $(35 \%$ of Karelia's moss flora) were found. This reflects the natural conditions of the KSNR, characterised by the predominance of felsic rocks and acid soils, pine forests, bogs and poor fens. Five species (Campyliadelphus elodes, Diobelonella palustris, Eurhynchium angustirete, Sphagnum auriculatum, and Neckera pennata) are listed in the Red Data Book of the Republic of Karelia (2020). They were found in the River Kamennaya or near this location. The current state of the Red Data Book moss species populations should be monitored. The moss flora of the KSNR is typical for the Karelian north taiga subzone, being poorly specific. Studies on the moss flora should be continued for a better understanding of the moss diversity in the KSNR.

\section{Acknowledgements}

The author is grateful to S.V. Tarkhov, Yu.A. Krasovsky (both - Kostomuksha State Nature Reserve, Russia), O.V. Galanina (Saint-Petersburg State University, Russia) for support in conducting field studies, E.A. Ignatova, V.E. Fedosov (Moscow State University, Russia) for identifying some moss species, T.I. Brazovskaya, S.R. Znamensky (both - Karelian Research Centre of RAS, Russia) for preparing figures, and G.N. Sokolov (Karelian Research Centre of RAS, Russia) for translating the manuscript into English. The studies were carried out under the State Assignment for the Institute of Biology, Karelian Research Centre of RAS (№AAAA-A19-119062590056-0).

\section{Supporting Information}

The moss species composition in the Kostomuksha State Nature Reserve (Electronic Supplement 1. The annotated list of moss species of the Kostomuksha State Nature Reserve, Russia), and its comparison with four other Protected Areas in European Russia, along the country borders, in the north-taiga (Electronic Supplement 2. Moss species in the Kostomuksha State Nature Reserve (KSNR) and four Protected Areas in European Russia, along the country borders, in the north-taiga) may be found in the Supporting Information.

\section{References}

Afonina O.M., Andreeva E.N., Baisheva E.Z., Bakalin V.A., Bezgodov A.G., Borovichev E.A., Cherdant- 
seva V.Ya., Czernyadjeva I.V., Fedosov V.E., Ignatov M.S., Ignatova E.A., Ivanov O.V., Ivanova E.I., Karmazina E.V., Kharzinov Z.Kh., Konstantinova N.A., Kotkova V.M., Maksimov A.I., Maksimova T.A., Mamontov Yu.S., Notov A.A., Nyushko T.I., Potemkin A.D., Savchenko A.N., Schestakova A.A., Schilnikov D.S., Shkaraba E.M., Tubanova D.Ya., Zolotov V.I. 2009. New records. Arctoa 18: 249-287. DOI: $10.15298 /$ arctoa.18.19

Afonina O.M., Akatova T.V., Andreeva E.N., Baisheva E.Z., Belkina O.A., Bezgodov A.G., Borovichev E.A., Boychuk M.A., Czernyadjeva I.V., Doroshina G.Ya., Dulin M.V., Fedosov V.E., Ignatov M.S., Ignatova E.A., Konstantinova N.A., Krivobokov L.V., Kučera J., Kushevskaya E.V., Maksimov A.I., Maksimova T.A., Mamontov Yu.S., Notov A.A., Philippov D.A., Potemkin A.D., Ryazanova D.T., Savchenko A.N., Schilnikov D.S., Sofronova E.N., Tubanova D.Ya., Urbanavichene I.N. et al. 2010. New bryophyte records. Arctoa 19: 259-288. DOI: 10.15298/arctoa. 19.24

Aleksandrova V.D., Jurkovskaya T.K. 1989. Geobotanical division of the non-chernozem European USSR. Leningrad: Nauka. 63 p. [In Russian]

Auer A.V. 1942. Taydentavia tietoja Kuusamon Lehtisammakasvistosta. Annales Botanici Societatis Zoologicae-Botanicae Fennicae «Vanamo» 16(7): 34-46.

Bakhmet O.N., Medvedeva M.V., Raevsky B.V., Novikov S.G., Shelekhova T.S. 2021. Characteristics of soils and the soil cover in the Kostomuksha State Nature Reserve, Russia. Nature Conservation Research 6(Suppl.1): 43-56. DOI: 10.24189/ncr.2021.004

Belousova N.A., Danilov P.I., Zimin V.B., Korshunov G.T., Kuznetsov O.L. 1988. Kostomuksha State Nature Reserve. In: V.E. Sokolov, E.E. Syroechkovsky (Eds.): State Nature Reserves of the USSR. State Nature Reserves of the European part of the RSFSR. Part 1. Moscow: Mysl'. P. 90-100. [In Russian]

Borovichev E., Boychuk M. 2019. Additions to the flora of bryophyte of the Pasvik Reserve (Pechenga District, the Murmansk Region, Russia). Transactions Kola Science Centre 7: 123-127. DOI: 10.25702/ KSC.2307-5252.2019.4.123-127 [In Russian]

Boychuk M., Borovichev E. 2018. Checklist of mosses of the Pasvik State Nature Reserve (Murmansk Region, Russia). Folia Cryptogamica Estonica 55: 33-43. DOI: $10.12697 /$ fce.2018.55.05

Boychuk M.A. 1998. Bryoflora of the planned Kalevalsky National Park. In: Biodiversity, dynamics and protection of mire ecosystems in Eastern Fennoscandia. Petrozavodsk: Karelian Research Centre of RAS. P. 117-132. [In Russian]

Boychuk M.A. 2001. On the moss flora of Kostomuksha State Nature Reserve and the environs of the City of Kostomuksha, Karelia. Novosti Sistematiki Nizshikh Rastenii 35: 217-229. [In Russian]
Boychuk M.A., Galanina O.V. 2018. On the moss flora of the islands of Lake Kamennoe (Kostomuksha State Nature Reserve, Karelia). Transactions of Karelian Research Centre of Russian Academy of Science 8: 147-153. DOI: 10.17076/bg708 [In Russian]

Boychuk M.A., Lantratova A.S. 2009. Bryophytes of Karelia. Petrozavodsk: Petrozavodsk State University. 186 p. [In Russian]

Brotherus V.F. 1923. Die Laubmoose Fennoskandias. Flora Fennica 1: 1-635.

Gorkovets V.Y., Rayevskaya M.B. 1997. Geology of the Kostomuksha Nature Reserve. In: T. Lindholm, R. Heikkilä, M. Heikkilä (Eds.): Ecosystems, fauna and flora of the Finnish-Russian Nature Reserve Friendship. The Finnish Environment. Vol. 124. Helsinki: Publisher of Finnish Environment Institute. P. 11-18.

Gromtsev A.N. 2009. Forests of Kostomuksha State Nature Reserve: structure, dynamics, landscape patterns. Transactions of Karelian Research Centre of Russian Academy of Science 2: 71-78. [In Russian]

Hällström E. 1937. Anmärkningsvärda bladmossor fran provinsen Kuusamo. Memoranda Societatis pro Fauna et Flora Fennica 13: 93-95.

Halonen P., Ulvinen T. 1996. The bryoflora of the Paanajarvi National Park. Oulanka Reports 16: 23-32.

Hammer Ø., Harper D.A.T., Ryan P.D. 2001. PAST: Paleontological statistics software package for education and data analysis. Palaeontologia Electronica 4(1): 9 .

Hodgetts N., Cálix M., Englefield E., Fettes N., García Criado M., Patin L., Nieto A., Bergamini A., Bisang I., Baisheva E., Campisi P., Cogoni A., Hallingbäck T., Konstantinova N., Lockhart N., Sabovljevic M., Schnyder N., Schröck C., Sérgio C., Sim-Sim M., Vrba J., Ferreira C.C., Afonina O., Blockeel T., Blom H., Caspari S., Gabriel R., Garcia C., Garilleti R., González Mancebo J. et al. 2019. A miniature world in decline: European Red List of Mosses, Liverworts and Hornworts. Brussels: IUCN. 87 p. DOI: 10.2305/ IUCN.CH.2019.ERL.2.en

Hodgetts N.G., Söderström L., Blockeel T.L., Caspari S., Ignatov M.S., Konstantinova N.A., Lockhart N., Papp B., Schröck C., Sim-Sim M., Bell D., Bell N.E., Blom H.H., Bruggeman-Nannenga M.A., Brugués M., Enroth J., Flatberg K.I., Garilleti R., Hedenäs L., Holyoak D.T., Hugonnot V., Kariyawasam I., Köckinger H., Kučera J., Lara F., Porley R.D. 2020. An annotated checklist of bryophytes of Europe, Macaronesia and Cyprus, Journal of Bryology 42(1): 1-116. DOI: 10.1080/03736687.2019.1694329

Hyvärinen E., Juslén A., Kemppainen E., Uddström A., Liukko U.M. 2019. The 2019 Red List of Finnish Species. Helsinki: Publisher of Finnish Environment Institute. 704 p.

Kalliola R. 1939. Pflansensoziologische Untersuchungen in der alpinen Stufe Finnisch-Lapplands. Annales 
Botanici Societatis Zoologicae-Botanicae Fennicae «Vanamo»13: 1-321.

Kolomytsev V.A., Kuznetsov O.L. 1997. Mires and paludified forests of the Kostomuksha Nature Reserve. In: T. Lindholm, R. Heikkilä, M. Heikkilä (Eds.): Ecosystems, fauna and flora of the Finnish-Russian Nature Reserve Friendship. The Finnish Environment. Vol. 124. Helsinki: Publisher of Finnish Environment Institute. P. 53-62.

Koponen T. 1967. Eurhynchium angustirete (Broth.) T. Kop. comb.n. (= E. zetterstedtii Störm.) and its distribution pattern. Memoranda Societatis pro Fauna et Flora Fennica 43: 53-59.

Mäkirinta U., Sipola M., Nuotio P. 1997. On the aquatic flora and vegetation of the northern half of the isoetid Lake Kiitehenjärvi in the Kostomuksha Nature Reserve. In: T. Lindholm, R. Heikkilä, M. Heikkilä (Eds.): Ecosystems, fauna and flora of the FinnishRussian Nature Reserve Friendship. The Finnish Environment. Vol. 124. Helsinki: Publisher of Finnish Environment Institute. P. 99-113.

Maksimov A.I. 1995. Mosses of the Paanajarvi National Park. In: Nature and ecosystems of Paanajärvi National Park. Petrozavodsk: Karelian Research Centre of RAS. P. 84-107. [In Russian]

Maksimov A.I., Boychuk M.A. 2011. Diversity of bryophytes in operating and planned protected areas in the Karelian part of the Green Belt of Fennoscandia. Transactions of Karelian Research Centre of Russian Academy of Science 2: 100-106. [In Russian]

Maksimov A.I., Maksimova T.A. 2008. Mosses. In: Bedrock landscapes of the Karelian White Sea shore: nature, economic development and protection. Petrozavodsk: Karelian Research Centre of RAS. P. 93-99. [In Russian]

Maksimov A.I., Maksimova T.A. 2018. Additions to the moss flora of Petrozavodsk. Transactions of Karelian Research Centre of Russian Academy of Science 1: 97-102. [In Russian]

Maksimov A.I., Maksimova T.A., Boychuk M.A. 2003. Mosses. In: Biotic diversity of Karelia: conditions of formation, communities and species. Petrozavodsk: Publisher of the Karelian Research Centre of RAS. P. 105-119. [In Russian]

Maksimov A.I., Kuznetsov O.L., Maksimova T.A. 2009. Moss flora of the planned national park «Tulos» (Republic of Karelia). Novosti Sistematiki Nizshikh Rastenii 43: P. 362-376. [In Russian]

Pesola V.A. 1934. Über die Felsenvegetation in NE-Kuusamo und SE-Kuolajärvi. Annales Botanici Societatis Zoologicae-Botanicae Fennicae «Vanamo» 5: 1-17.
Ramenskaya M.L. 1960. Handbook of Karelian higher plants. Petrozavodsk: Publisher of KASSR. 485 p. [In Russian]

Red Data Book of the Republic of Karelia. Belgorod: Konstanta, 2020. 448 p. [In Russian]

Roivainen H. 1929. Lisätietoja eräiden lehtisammallajien esiintymisestä maassamme. Annales Botanici Societatis Zoologicae-Botanicae Fennicae «Vanamo» 9: 286-297.

Salo Y. 1997. Principal characteristics of climate of the Kostomuksha Nature Reserve. In: T. Lindholm, R. Heikkilä, M. Heikkilä (Eds.): Ecosystems, fauna and flora of the Finnish-Russian Nature Reserve Friendship. The Finnish Environment. Vol. 124. Helsinki: Publisher of Finnish Environment Institute. P. 25-29.

Sofronova E.N., Abakarova A.S., Afonina O.M., Badmaeva N.K., Borovichev E.A., Boychuk M.A., Czernyadjeva I.V., Doroshina G.Ya., Dulin M.V., Dyachenko A.P., Fedosov V.E., Ibatullin A.A., Ignatov M.S., Ignatova E.A., Ivanova E.I., Ivchenko T.G., Kokoshnikova Yu.S., Kozhin M.N., Kuzmina E.J., Maksimov A.I., Maksimova T.A., Malashkina E.V., Mamontov Yu.S., Moshkovskij S.A., Notov A.A., Philippov D.A., Potemkin A.D., Preobrazhenskaya E.S., Taran G.S., Teplov K.Yu. et al. 2012. New bryophyte records. 1. Arctoa 21: 275-300. DOI: 10.15298/arctoa.21.27

Sofronova E.V., Andrejeva E.N., Bakalin V.A., Beldiman L.N., Belyakov E.A., Blagovetshenskiy I.V., Borovichev E.A., Boychuk M.A., Doroshina G.Ya., Dulin M.V., Fedosov V.E., Garin E.V., Ginzburg E.G., Golovina E.O., Grishutkin O.G., Ignatov M.S., Ignatova E.A., Konstantinova N.A., Kopeina E.I., Kozhin M.N., Makarova M.A., Maksimov A.I., Maksimova T.A., Mamontov Yu.S., Nikolajev I.A., Pisarenko O.Yu., Popova N.N., Schestakova A.A., Teleganova V.V., Tikhonov A.V. 2017. New bryophyte records. 8. Arctoa 26(1): 105-124. DOI: 10.15298/arctoa.26.11

Tamarin P.V., Schmidt V.M. 1975. Comparative analysis of some similarity indexes. Proceedings of the Leningrad Society of Naturalists 72(5): 45-54. [In Russian]

Tuomikoski R. 1939. Materialien zu einer Laubmoosflora des Kuusamo-Gebietes. Annales Botanici Societatis Zoologicae-Botanicae Fennicae «Vanamo» 12(4): $1-124$.

Volkova L.A., Maksimov A.I. 1993. Check-list of Karelia's mosses. In: Karelia's plant kingdom and protection problems. Petrozavodsk: Karelian Research Centre of RAS. P. 57-91. [In Russian]

Wahlberg H. 1998. The collections of threatened bryophytes from Ladoga Karelia in Finnish Herbaria. Arctoa 7: 37-44. 


\title{
МХИ (ВRYОРНУТА) ЗАПОВЕДНИКА «КОСТОМУКШСКИЙ» (РОССИЯ)
}

\author{
М. А. Бойчук \\ Институт биологии Карельского научного иентра РАН, Россия \\ e-mail:boychuk@krc.karelia.ru
}

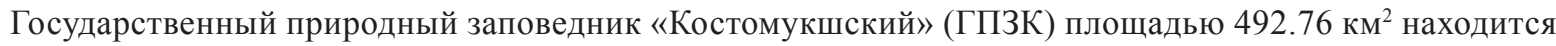
на северо-западе России, на территории Республики Карелия (далее - Карелия), у границы с Финляндией. Он создан в 1983 г. с целью сохранения типичного участка северотаежной подзоны Европейской России. В статье подведены итоги многолетней инвентаризации мхов. Критически проверены собственные сборы (1995-1998, 2016 гг.), хранящиеся в Гербарии Карельского научного центра PAH (PTZ). Были обработаны личные сборы 2010, 2012, 2017-2019 гг., и учтены литературные источники. На основании обобщения всего доступного материала составлен аннотированный список мхов ГПЗК, насчитывающий 180 видов. Это составляет 70\% флоры мхов Куйтозеро-Лексозерского флористического района и 35\% - Карелии. Впервые для флоры мхов ГПЗК приводятся 26 видов. Из них шесть видов (Campyliadelphus elodes, Racomitrium fasciculare, Didymodon rigidulus, Eurhynchium angustirete, Grimmia elatior, Grimmia torquata) являются новыми для Куйтозеро-Лексозерского флористического района. Обнаружены новые местонахождения ранее известных видов. Определены особенности флоры мхов ГПЗК на основе таксономического и эколого-ценотического анализа. Большинство видов $(75 \%)$ широко распространено в подзоне северной тайги Карелии. Выявлено пять видов, внесенных в Красную книгу Республики Карелия (2020 г.): Campyliadelphus elodes (3 VU), Eurhynchium angustirete (3 VU), Neckera pennata (3 NT), Diobelonella palustris (= Dichodontium palustre) (3 VU), Sphagnum auriculatum (3 VU). Для первых трех охраняемых видов ГПЗК является самым северным местонахождением, а для Diobelonella palustris - единственным местонахождением в Карелии. Девять видов (Callicladium haldanianum (NT), Campyliadelphus elodes (NT), Dicranum spadiceum (VU), Mnium lycopodioides (NT), Neckera pennata (VU), Schistostega pennata (VU), Sphagnum contortum (NT), Sphagnum inundatum (EN), Sphagnum subnitens (NT)) включены в Красный список Финляндии (2019 г.), семь видов (Campyliadelphus elodes (NT), Fontinalis dalecarlica (NT), Helodium blandowii (NT), Meesia triquetra (NT), Scorpidium scorpioides (NT), Splachnum ampullaceum (NT), Tomentypnum nitens (NT)) включены в Красный список Европы (2019 г.). Проведено сравнение флоры мхов ГПЗК с таковыми четырех приграничных северотаежных ООПТ Европейской России: заповедник «Пасвик» (Мурманская область), национальные парки «Паанаярви» и «Калевальский», планируемый заказник «Тулос» (все три - Карелия).

Ключевые слова: виды, Красная книга, образец, особо охраняемая природная территория, флора 